Якимова Н.С., кандидат економічних наук, доцент, Донецький національний університет імені Василя Стуса ORCID: 0000-0001-5278-1142 n.yakimova@donnu.edu.ua

\title{
МОНІТОРИНГ ПОВЕДІНКОВИХ МОДЕЛЕЙ СУБ'ЄКТІВ РИНКУ ПРАЦІ В СИСТЕМІ ІНФОРМАЦІЙНО-АНАЛІТИЧНОГО ЗАБЕЗПЕЧЕННЯ ДЕРЖАВНОЇ ПОЛІТИКИ
}

У статті запропоновано методологію визначення поведінкових моделей суб'єктів ринку праці та забезпечення їх моніторингу в системі інформаційно-аналітичного забезпечення державної політики. Розроблено алгоритм визначення, типологізації та регулювання поведінкових моделей суб'єктів ринку праці, щцо складається з наступних етапів: проведення дослідження поведінкових моделей суб'єктів ринку праці з метою виявлення їх видів та типів, визначення чинників впливу на їх формування та розвиток; групування чинників, щуо найбільш істотно впливають на формування та розвиток поведінкових моделей суб'єктів ринку прачі; виділення факторів, які визначають особливості поведінкових моделей суб'єктів ринку праці, та характерних ознак, щэо їм притаманні; виявлення та систематизація критерїв віднесення до певного типу поведінкових моделей суб'єктів ринку прачі; розробка методичних основ створення комплексної системи оцінки наявних на ринку праці поведінкових моделей його суб'єктів; аналіз поточної ситуачії на ринку праці та прогнозування ї̈ розвитку у короткостроковій $i$ довгостроковій перспективі для своєчасного виявлення та коригування існуючих поведінкових моделей суб'єктів ринку прачі; забезпечення передумов для стимулювання розвитку та поширення ефективних поведінкових моделей суб'єктів ринку праці; моніторинг змін типів та видів поведінкових моделей суб'єктів ринку прачі з метою своєчасного виявлення, ідентифікації та підтримки з боку держави та бізнесу.

Ключові слова: поведінкові моделі, ринок прачі, державна політика, методологія, алгоритм, моніторинг, інформачійно-аналітичне забезпечення.

Рис. -1 , Літ. -10 .

Якимова Н.С., кандидат экономических наук, доцент, Донецкий национальный университет имени Васыля Стуса

ORCID: 0000-0001-5278-1142

n.yakimova@donnu.edu.ua

\section{МОНИТОРИНГ ПОВЕДЕНЧЕСКИХ МОДЕЛЕЙ СУБЪЕКТОВ РЫНКА ТРУДА В СИСТЕМЕ ИНФОРМАЦИОННО- АНАЛИТИЧЕСКОГО ОБЕСПЕЧЕНИЯ ГОСУДАРСТВЕННОЙ ПОЛИТИКИ}


В статье предложена методология определения поведенческих моделей субъектов рынка труда и обеспечения их мониторинга в системе информационно-аналитического обеспечения государственной политики. Разработан алгоритм определения, типологизаџии и регулирования поведенческих моделей субъектов рынка труда, который состоит из следующих этапов: проведение исследования поведенческих моделей субъектов рынка труда с иелью выявления их видов и типов, определение факторов влияния на их формирование и развитие; группировка факторов, наиболее существенно влияющих на формирование и развитие поведенческих моделей субъектов рынка труда; выделение факторов, определяющих особенности поведенческих моделей субъектов рынка труда, и признаков, которые им характерны; выляление и систематизация критериев отнесения к определенному типу поведенческих моделей субъектов рынка труда; разработка методических основ создания комплексной системы оценки имеющихся на рынке труда поведенческих моделей его субъектов; анализ текущей ситуации на рынке труда и прогнозирование ее развития в краткосрочной $и$ долгосрочной перспективе для своевременного выявления $и$ корректировки существующих поведенческих моделей субъектов рынка труда; обеспечение условий для стимулирования развития и распространения эффективных поведенческих моделей субъектов рынка труда; мониторинг изменений типов и видов поведенческих моделей субъектов рынка труда с иелью своевременного выявления, идентификации и поддержки со стороны государства и бизнеса.

Ключевые слова: поведенческие модели, рынок труда, государственная политика, методология, алгоритм, мониторинг, информационно-аналитическое обеспечение.

Рис. - 1, Лит. -10.

\section{N. Yakymova,}

$\mathrm{PhD}$ in Economics, Associate Professor, Vasyl' Stus Donetsk National University ORCID: 0000-0001-5278-1142 n.yakimova@donnu.edu.ua

\section{MONITORING OF BEHAVIORAL MODELS OF LABOR MARKET ACTORS IN THE SYSTEM OF INFORMATION AND ANALYTICAL SUPPORT OF STATE POLICY}

In the article the methodology for determining the behavioral models of labor market actors and ensuring their monitoring in the system of information and analytical support of public policy is proposed. An algorithm for defining, typologizing and regulating the behavioral models of labor market actors has been developed, consisting of the following stages: a study of behavioral models of labor market actors to identify their species and types, to determine the factors influencing their formation and development; grouping of factors that most significantly affect the formation and development of behavioral models of labor market actors; identification of factors that determine the characteristics of behavioral models of labor market actors, and the characteristics that are inherent in them; identification and systematization of criteria for assignment to a certain type of behavioral models of labor market actors; development of methodological bases for creating a comprehensive system for assessing the behavioral models of its actors available on the labor market; analysis of the current situation in the labor market and forecasting its development in the short and long term for timely identification and adjustment of existing behavioral models of labor market actors; providing 
preconditions for stimulating the development and dissemination of effective behavioral models of labor market actors; monitoring changes in the types and kinds of behavioral patterns of labor market actors in order to timely identify, identify and support the state and business.

Keywords: behavioral models, labor market, state policy, methodology, algorithm, monitoring, information and analytical support.

Fig. -1 , Ref. -10 .

Постановка проблеми. Сьогодні основу ефективного державного регулювання становить інформація. Інформаційні потоки даних про об'єкт регулювання та його навколишнє середовище відіграють визначальну роль на всіх етапах прийняття та реалізації управлінських рішень. Особливу значущість механізми отримання та обробки інформації набувають в контексті регулювання поведінкових моделей суб'єктів ринку праці, сутністю якого є здатність здійснювати такий управлінський вплив, що адекватно реагує на зміни як зовнішньої (інституційного та ринкового), так і внутрішнього середовища шляхом прийняття ефективних управлінських рішень. Дослідження процесів адаптації тих чи інших суб'єктів до мінливих умов зовнішнього середовища визначає коло основних чинників, що впливають на перебіг процесу. Однак перелік цих факторів у процесах, які динамічно розвиваються, постійно змінюється. Ця обставина значно ускладнює регулювання. У зв'язку 3 цим базовою частиною механізму державного регулювання поведінкових моделей суб'єктів ринку праці може стати їх моніторинг, тобто систематичний збір і аналіз інформації з метою виявлення тенденцій поведінки суб'єктів ринку праці.

Аналіз останніх досліджень і публікацій. Дослідженню поведінкових моделей суб'єктів ринку праці, а також виявленню їх сучасних типів та видів присвячено багато наукових праць українських та закордонних вчених, зокрема К. Безгіна [1], Л. Безтелесної, Г. Беккера [2], М. Вебера, Т. Веблена, О. Грішнової, Е. Дюркгейма, Т. Заславської [3], Д. Канемана [4], Р. Кеттела, А. Колота, М. Кондратьєва, К. Леонгарда, Е. Лібанової [5], І. Петрової [6], Т. Пікетті [7], М. Семикіної [8], А. Сміта, П. Сорокіна [9], Л. Шаульської [10] та ін. Водночас, сучасні економічні виклики вимагають більш грунтовного вивчення та розробки методології визначення поведінкових моделей суб'єктів ринку праці та забезпечення їх моніторингу в системі інформаційноаналітичного забезпечення державної політики, що зумовлює актуальність обраного напряму дослідження.

Метою статті є розробка методології визначення поведінкових моделей суб'єктів ринку праці та забезпечення їх моніторингу в системі інформаційно-аналітичного забезпечення державної політики.

Виклад основного матеріалу. У сучасних умовах в Україні активізується процес трансформації ринку праці, а також інституту зайнятості, що характеризується виникненням іiі нових форм та видів. За таких умов державна політика повинна бути націлена на поширення та сприяння переходу до сучасних інноваційних поведінкових моделей суб'єктів ринку праці. Саме тому виокремлення нових рис моделей поведінки суб'єктів ринку праці та визначення перспектив їх регулювання $\epsilon$ актуальним та потребує більш детального дослідження.

На основі проведених теоретичних досліджень, доцільно запропонувати алгоритм визначення, типологізації та регулювання поведінкових моделей суб'єктів ринку праці, що складається 3 наступних етапів: проведення дослідження поведінкових моделей суб'єктів ринку праці з метою виявлення їх видів та типів, визначення чинників впливу на їх формування та розвиток; групування чинників, що найбільш істотно впливають на 
формування та розвиток поведінкових моделей суб'єктів ринку праці; виділення факторів, які визначають особливості поведінкових моделей суб'єктів ринку праці, та характерних ознак, що їм притаманні; виявлення та систематизація критеріїв віднесення до певного типу поведінкових моделей суб'єктів ринку праці; розробка методичних основ створення комплексної системи оцінки наявних на ринку праці поведінкових моделей його суб'єктів; аналіз поточної ситуації на ринку праці та прогнозування іiі розвитку у короткостроковій і довгостроковій перспективі для своєчасного виявлення та коригування існуючих поведінкових моделей суб'єктів ринку праці; забезпечення передумов для стимулювання розвитку та поширення ефективних поведінкових моделей суб'єктів ринку праці; моніторинг змін типів та видів поведінкових моделей суб'єктів ринку праці з метою своєчасного виявлення, ідентифікації та підтримки з боку держави та бізнесу (рис. 1).

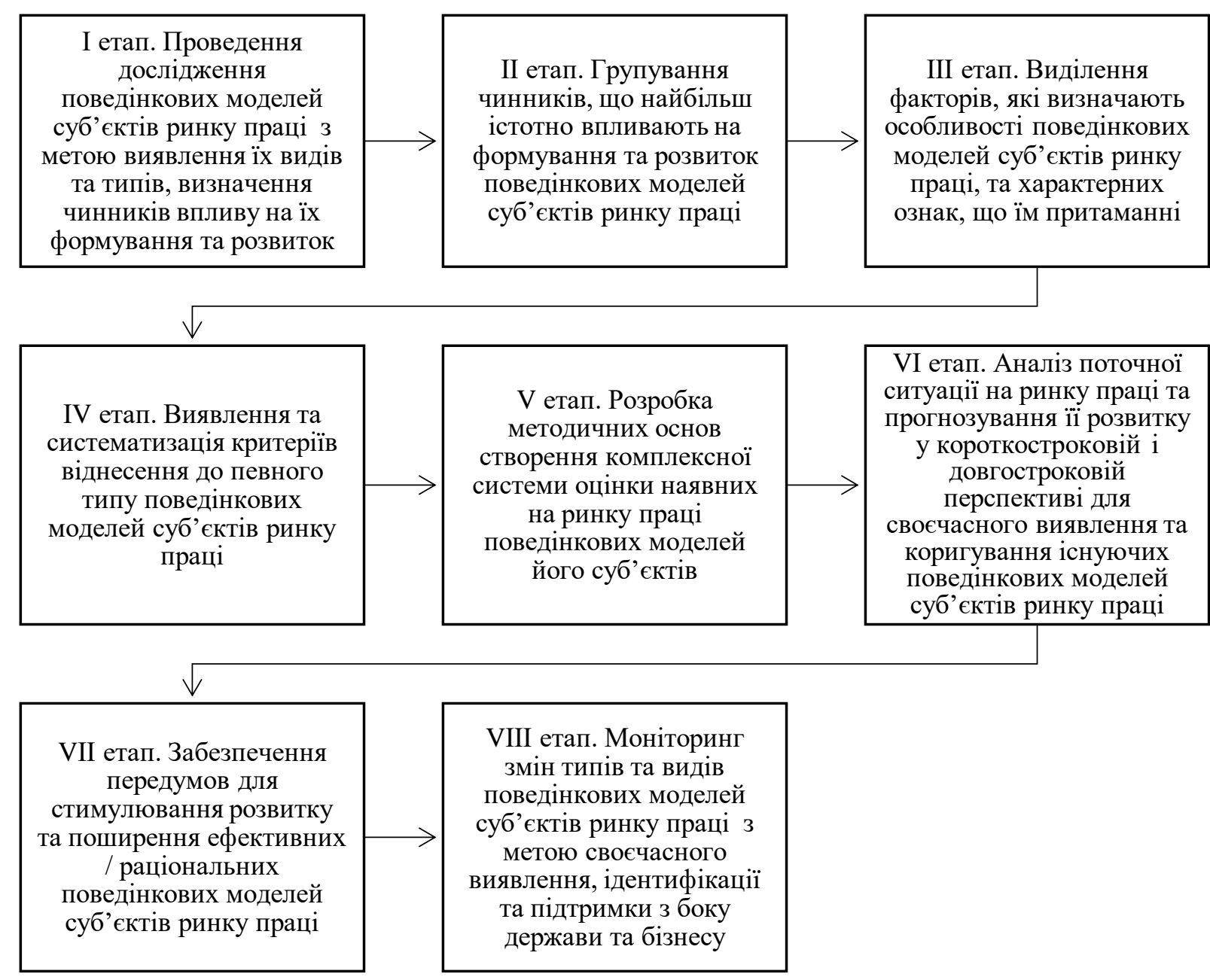

\section{Рисунок 1 - Алгоритм визначення, типологізації та регулювання поведінкових моделей суб'сктів ринку праці}

Розглянемо більш детально всі етапи запропонованого алгоритму визначення, типологізації та регулювання поведінкових моделей суб'єктів ринку праці. На I-му етапі здійснюється дослідження всіх наявних на ринку праці поведінкових моделей його суб'єктів. Даний етап покликаний виявити види та типи моделей поведінки, тобто здійснити їх узагальнення та типологізацію. Якщо орієнтуватись на інституціональні 
зміни, що відбуваються в Україні, то найбільш важливим критерієм типологізації поведінки є характер сприйняття індивідами нових соціально-економічних відносин та умов життєдіяльності. Найбільш актуальними та затребуваними у сучасних умовах $\epsilon$ адаптивні поведінкові моделі суб'єктів, що відповідають потребам економічної підсистеми суспільства та відображають поведінку, що орієнтована на зміни навколишнього середовища та пристосування до нього з метою задоволення власних потреб.

Також на I етапі визначаються чинники впливу на формування та розвиток поведінкових моделей суб'єктів ринку праці, що носять демографічний, політичний, економічний, соціальний, культурних та психологічний характер.

II етап алгоритму визначення, типологізації та регулювання поведінкових моделей суб'єктів ринку праці орієнтований на групування чинників, що найбільш істотно впливають на формування та розвиток моделей поведінки. За умов стрімкого розвитку нової економіки перед суб'єктами ринку праці постають нові виклики, що потребують швидкого реагування на них, а також постійного коригування їх поведінкових моделей. За таких умов доцільно виокремити наступні чинники, що впливають на поведінкові моделі суб'єктів ринку праці:

політичні, що характеризують законодавчу, нормативно-правову базу функціонування суб'єктів ринку праці; рівень довіри до влади та стабільність в країні, що дає змогу ефективного ведення бізнесу;

демографічні, що характеризують вплив статевовікових, подружніх та інших особливостей (освіта, мовна культура, структура родини) суб'єктів ринку праці на їх поведінкові моделі;

культурні, які впливають на стиль ведення бізнесу, укладання контрактів та ведення переговорів, а також релігійні, субкультурні традиції та установки;

соціальні, до яких відносяться: соціалізація особистості; рівень освіти; соціальні мережі; рекомендації колег, друзів, близьких родичів; приналежність до того чи іншого соціального класу;

психологічні, а саме: попередній досвід; тип особистості; мотивація до якогось поведінкового аспекту; склад характеру; переконання;

економічні: рівень доходу; темп інфляції; довіра до фінансових установ; рівень фінансової освіченості; умови договору (кредитного, страхового тощо); фіскальна та бюджетна політика держави; гарантії (держави або установи); життєвий цикл домогосподарства.

На III-му етапі виділяються фактори, що визначають особливості поведінкових моделей суб'єктів ринку праці, а також виокремлюються характерні ознаки, що їм притаманні. Фактори, що впливають на поведінкові моделі та визначають їх особливості, умовно можна поділити на:

фактори макрорівня: державно-правові фактори (діяльність держави в області податкової політики, трудового законодавства, захисту прав працюючих, державні гарантії зайнятості тощо), стан ринкової кон'юнктури (відображає сформовані співвідношення попиту та пропозиції ресурсів праці в розрізі всіх складових ринку праці), наявність резервів праці необхідної кваліфікації (чим вони більші, тим жорсткіші обмеження доступу в сферу прикладання праці, оскільки будь-яка сфера має певні рамки місткості);

фактори мікрорівня: стратегії роботодавців, що формуються виходячи зі стану сфер прикладання праці (стратегія підприємництва, зростання, прибутку, функціональної або 
чисельної гнучкості) - вони або підсилюють вибір нової моделі поведінки, або підтверджують правильність існуючої поведінкової моделі;

фактори особистісного рівня: вимоги до працівників (до освіти, досвіду, віку, кваліфікації, статі, здібностей та навичок), цільові орієнтири (самореалізація, успіх, добробут тощо), соціально-демографічні характеристики (розкривають життєвий ресурс та особистісну ситуацію суб'єкта та визначають ступінь свободи дій), тривалість, цінність і якість дозвілля (в силу обмеженості часового ресурсу, суб'єкт змушений ділити свій час між виробництвом реального доходу та відпочинком), джерела отримання доходів, доступність більш раціональних та вигідних напрямів використання наявних ресурсів (дозволяє ранжувати можливі об' єкти прикладання праці, виходячи 3 інформації про імідж цього об'єкта, про його прибутковість, а також визначає доступ до певних каналах працевлаштування).

IV етап алгоритму націлений на виявлення та систематизацію критеріїв віднесення до певного типу поведінкових моделей суб'єктів ринку праці. На сучасному етапі розвитку важливими критеріями віднесення до певного типу поведінкових моделей доцільно вважати наступні: високий рівень комунікативності (комунікативний потенціал), продукування нових знань, ідей та методів, здатність до навчання, самовдосконалення, критичність мислення, готовність до змін, можливість вирішення завдань нестандартними способами, нестандартне, нешаблонне мислення, відмова від стереотипів, адаптивність, цілеспрямованість, відкритість, мобільність, тощо. Слід зазначити, що типи поведінки не можуть бути достатньо чітко систематизовані, тобто не існує певних алгоритмів, що можуть бути однаково застосовані та будуть адекватно відображати поведінку суб'єктів в різних часових та просторових проміжках. Неминуче будуть 3'являтись нові типології, і теоретичні, і емпіричні, певні типології будуть застарівати через свою неспроможність або внаслідок появи нових, більш конструктивних та поглинаючих їх теорій.

Ha V-му етапі запропонованого алгоритму пропонується розробити методичні основи створення комплексної системи оцінки наявних на ринку праці поведінкових моделей його суб' єктів. Аналіз існуючих поведінкових моделей суб'єктів ринку праці вимагає наукової розробки інструментарію, що дозволяє проводити кількісну та якісну оцінку поточного стану і ступеня їх розвитку. Це передбачає розробку методологічних, методичних і аналітичних основ створення комплексної системи індикаторів і показників i ïx ефективності з соціально-економічної точки зору. При розробці такої системи доцільно керуватися наступними вимогами: забезпечення гнучкості, прозорості та доступності індикаторів та показників стосовно до різних умов їх вимірювання; аналіз достатньої кількості факторів, що визначають формування та розвиток поведінкових моделей суб'єктів ринку праці; розробка єдиних підходів, що забезпечать єдину методологічну основу i порівнянність показників для міждержавного аналізу процесів розвитку поведінкових моделей. Слід враховувати, що неможливо оцінити існуючі поведінкові моделі суб'єктів ринку праці за допомогою якого-небудь одного абсолютного або відносного показника. Набір змінних, що дозволяють оцінити зайнятість інноваційного типу, повинен забезпечувати отримання репрезентативних результатів. В рамках оцінки наявних на ринку праці поведінкових моделей його суб'єктів необхідно розглядати не тільки кількісні параметри, а й якісні характеристики. Для виявлення якісних параметрів може використовуватися метод експертної оцінки (опитування працівників, роботодавців, представників державних органів), що в подальшому дозволить формалізувати і зробити зручною процедуру збору і аналізу даних. 
VI етап спрямований на аналіз поточної ситуації на ринку праці та прогнозування iii розвитку у короткостроковій і довгостроковій перспективі для своєчасного виявлення та коригування існуючих поведінкових моделей суб'єктів ринку праці. Останніми десятиріччями у структурі зайнятості за видами економічної діяльності відбуваються постійні зміни, найбільш значними з яких є перевищення частки зайнятих у секторі послуг над часткою зайнятих у секторі сільського господарства, що обумовлено переміщенням джерела цінності й багатства зі сфери матеріального виробництва у сферу виробництва нематеріального знання. Саме тому задля своєчасного виявлення нових поведінкових моделей суб'єктів ринку праці необхідним є постійний аналіз ситуації на ринку праці та прогнозування його розвитку у короткостроковій та довгостроковій перспективі.

На VII-му етапі запропонованого алгоритму передбачено виокремлення передумов для стимулювання розвитку та поширення ефективних поведінкових моделей суб'єктів ринку праці. На етапі прийняття рішення щодо вибору тієї чи іншої поведінкової моделі суб'єкти ринку праці враховують певні спільні економічні інтереси, а саме: співучасть виробничого персоналу в управлінні, власності та фінансовій діяльності підприємств; накопичення людського капіталу; стійке зростання в довгостроковій перспективі; досягнення високої якості життя; досягнення соціальної стабільності в суспільстві; ефективність праці і суспільного відтворення; забезпечення безпеки праці; дотримання соціальних стандартів; людський і соціальний розвиток. Але не завжди поведінковим моделям суб'єктів ринку праці притаманна раціональність. Тобто, поведінкова модель «людини економічної» найкращим чином підходить для опису систематично раціональної частини людської поведінки. Але наразі в економіці спостерігається поступова трансформація поведінкових моделей під впливом не тільки економічних індикаторів, а й інтуїтивних суджень, когнітивних викривлень, асиметрії інформаційних потоків, дій інших індивідів тощо. Зазначені фактори призводять до відхилення від раціональної моделі поведінки, а тому поведінкові моделі суб'єктів ринку праці в таких умовах все частіше характеризуються ірраціональністю. Тому передумовами, що сприятимуть розвитку інноваційної зайнятості повинні стати: удосконалення законодавчої бази, що регулює та стимулює взаємовідносини між суб'єктами господарювання та державою; забезпечення високої якості формування ресурсів праці, підвищення рівня їх кваліфікації, професійних навиків, досвіду роботи, забезпечення високого рівня інноваційності, мобільності, адаптованості працівників; підвищення науково-технічного та інноваційного рівня економіки; розвиток нестандартних, гнучких форм зайнятості, що є резервом підвищення рівня зайнятості; підвищення гнучкості ринку праці та виробництва, розширення сектору послуг; збільшення частки високотехнологічних виробництв, зростання сектора послуг; створення економічних можливостей для населення за допомогою розробки і реалізації економічної політики, спрямованої на розвиток нових інноваційних та збереження існуючих робочих місць; стимулювання творчості, активності та ініціативи працівників, забезпечення формування необхідних професійних навичок та компетенцій, тощо.

VIII етап передбачає проведення моніторингу змін типів та видів поведінкових моделей суб'єктів ринку праці 3 метою своєчасного виявлення, ідентифікації та підтримки з боку держави та бізнесу.

Відмінність моніторингу поведінкових моделей суб’єктів ринку праці від моніторингу економічних та фінансових аспектів діяльності господарюючого суб'єкта, який використовується для фінансово-господарського аналізу, полягає в тому, що при моніторингу поведінкових моделей суб'єктів ринку праці огляд аналітичних даних 
охоплює більший спектр показників, в тому числі соціальні процеси, що відбуваються в суспільстві, взаємозв'язок соціально-економічних і психологічних факторів. Якщо аналіз фінансово-господарської діяльності є основою для складання прогнозних планів розвитку країни, то моніторинг поведінкових моделей, в першу чергу, орієнтований на процес прийняття рішень управлінського та регулюючого характеру. Отже, моніторинг поведінкових моделей суб'єктів ринку праці можна визначити як комплексну систему безперервного спостереження, аналізу та короткострокового прогнозування соціальноекономічного процесу, що становить основну ланку на етапі підготовки, прийняття та контролю виконання управлінського рішення.

Так як сучасне ринкове середовище $\epsilon$ мінливим i складним, a також характеризується високим рівнем невизначеності, то інформація, що отримується за допомогою моніторингу, повинна відповідати критеріям оперативності, достовірності та безперервності. В умовах невизначеності особливого значення набуває забезпечення несуперечності одержуваної з різних джерел (рівнів управління) інформації. Рішенням даної проблеми в моніторингу поведінкових моделей суб'єктів ринку праці $\epsilon$ взаємодоповнення та порівняння показників, отриманих за допомогою методу експертної оцінки, з офіційно затвердженими статистичними даними. Це дозволяє отримувати повне уявлення про існуючі поведінкові моделі суб’єктів ринку праці. Оцінку поведінкових моделей необхідно здійснювати постійно, що значно збільшує ступінь контролю над змінами, які відбуваються в суспільстві.

Моніторинг поведінкових моделей суб'єктів ринку праці сприяє утворенню певного механізму регулювання їх економічної поведінки - гнучкої системи організації їх діяльності, безперервного функціонування та подальшого економічного розвитку. Механізм державного регулювання поведінкових моделей представляє собою єдність основних етапів моніторингу та аналізу впливу факторів зовнішнього середовища як основи вирішення питань гнучкого управління та коригування поведінкових моделей суб'єктів ринку праці.

Таким чином, моніторинг стає фундаментом комплексної системи визначення змін типів та видів поведінкових моделей суб'єктів ринку праці, їх адаптації до умов зовнішнього середовища, що передбачає розробку механізму змін типів та видів поведінкових моделей суб'єктів ринку праці, що реалізується за допомогою впровадження концепції гнучкого управління.

Висновки. Сучасні проблеми розвитку суспільства активізують інтерес до дослідження моделей поведінки індивідів. Дана тенденція обгрунтована тим, що економічна поведінка визначає дії індивідів та їх реакції, що відображають зміни, які відбуваються на ринку праці, а також $є$ інструментом, що дозволяє передбачити результати трансформацій складових ринку. Ефективність трансформацій має високу залежність від того, наскільки адекватно відбувається формування та коригування компонентів поведінки індивідів в сучасні економічні відносини. Складність вибору моделей поведінки суб'єктів ринку праці в новій економіці полягає у тому, що їх економічні рішення приймаються в умовах невизначеності зовнішнього середовища під впливом динамічних змін економічних, політичних, демографічних, психологічних та інших чинників. Від правильно обраних моделей поведінки всіх суб'єктів ринку праці залежить ефективність їх співпраці, а також ті вигоди на ринку праці, які отримає кожен 3 них.

Отже, дослідження подальших трансформацій поведінкових моделей суб'єктів ринку праці, а також впровадження запропонованої методології визначення поведінкових моделей суб'єктів ринку праці дозволять спрогнозувати появу відхилення 
від раціональної моделі поведінки, визначити можливі результати (позитивні чи негативні) такої поведінки, оцінити рівень вірогідності їі існування та появи зазначених факторів у конкретній ситуації, здійснювати вплив на існуючі поведінкові моделі суб'єктів ринку праці, а також коригувати їх з метою отримання найбільш оптимальної моделі поведінки.

\section{СПИСОК ВИКОРИСТАНИХ ДЖЕРЕЛ}

1. Безгін К. С., Ушкальов В. В. Поведінкова економіка: епістемічний поворот у трактуванні раціональності. Економіка Украӥни. 2019. №7-8 (692-693). С. 3-15.

2. Беккер Г.С. Экономический анализ и человеческое поведение. Thesis. Teория $u$ история экономических и сочиальных институтов и систем. 1993. Т. 1, Вып. 1. С. 24-38.

3. Заславская T. Поведение массовых общественных групп как фактор трансформации общества. Мониторинг общественного мнения: экономические и соииальные перемены. 2000. №6. С. 13-19.

4. Tversky A., Kahneman D. Rational Choice and the Framing of Decisions. The Journal of Business. 1986. Vol. 59, № 4. Part 2. P. 251-278.

5. Людський розвиток в Україні. Інноваційні види зайнятості та перспективи їх розвитку (кол. моногр.) / за ред. Е.М. Лібанової; Ін-т демографії та соціальних досліджень ім. М.В. Птухи НАН України. К., 2016. 328 с.

6. Петрова І.Л., Близнюк В.В. Основні тенденції розвитку вітчизняного ринку праці: нові виклики та імперативи розвитку. Украйнський ринок праці: імперативи та можливості змін: кол. монографія / за наук. ред. д.е.н., проф. І.Л. Петрової, к.е.н. В.В. Близнюк; НАН України, ДУ «Ін-т екон. та прогнозув. НАН України». К., 2018. С. 8-27.

7. Пікетті Т. Капітал у XXI столітті. К.: Наш Формат, 2016. 696 с.

8. Семикіна М.В., Пасєка А.С. Ринок праці України: тенденції та особливості розвитку. Вісник Хмельницького національного університету. Економічні науки. 2016. № 5(1). C. $165-170$.

9. Сорокин П. Человек. Цивилизация. Общество. М., 1992.

10. Шаульська Л. В. Нові риси сфери зайнятості та перспективи іiі регулювання. Теоретичні і практичні аспекти економіки та інтелектуальної власності. 2015. Вип. 2(1). C. 120-128.

\section{REFERENCES}

1. Bezghin K. S., Ushkalov V. V. (2019) Povedinkova ekonomika: epistemichnyi povorot u traktuvanni ratsionalnosti [Behavioral economics: an epistemic turn in the interpretation of rationality]. Ekonomika Ukrainy, Vol. 7-8 (692-693), pp. 3-15. (in Ukrainian)

2. Bekker G.S. (1993) Ekonomicheskiy analiz i chelovecheskoe povedenie [Economic analysis and human behavior]. Thesis. Teoriya $i$ istoriya ekonomicheskih $i$ sotsialnyih institutov i system, no 1, pp. 24-38. (in Russian)

3. Zaslavskaya T. (2000) Povedenie massovyih obschestvennyih grupp kak faktor transformatsii obschestva [The behavior of mass social groups as a fact of the transformation of society]. Monitoring obschestvennogo mneniya: ekonomicheskie i sotsialnyie peremenyi, no 6, pp. 13-19. (in Russian)

4. Tversky A., Kahneman D. (1986) Rational Choice and the Framing of Decisions. The Journal of Business, Vol. 59, no. 4, Part 2, pp. 251-278. (in English)

5. Libanova E.M. (Eds.). (2016) Lyuds'kyy rozvytok v Ukrayini. Innovatsiyni vydy zaynyatosti ta perspektyvy yikh rozvytku [Human development in Ukraine. Innovative types of 
employment and prospects for their development]. kol. monohrafiya [a monograph]. K., In-t demohrafiyi ta sotsial'nykh doslidzhen' im. M.V. Ptukhy NAN Ukrayiny. 328 p. (in Ukrainian) 6. Petrova I.L., Blyzniuk V.V. (2018) Osnovni tendentsii rozvytku vitchyznianoho rynku pratsi: novi vyklyky ta imperatyvy rozvytku [The main trends in the domestic labor market: new challenges and development imperatives]. Ukrainskyi rynok pratsi: imperatyvy ta mozhlyvosti zmin [Ukrainian labor market: imperatives and opportunities for change]. kol. monohrafiia [a monograph]. K., NAN Ukrainy, DU «In-t ekon. ta prohnozuv. NAN Ukrainy», pp. 8-27. (in Ukrainian)

7. Piketti T. (2016) Kapital u XXI stolitti [Capital in the XXI century]. K.: Nash Format. 696 p. (in Ukrainian)

8. Semykina M.V., Pasieka A.S. (2016) Rynok pratsi Ukrainy: tendentsii ta osoblyvosti rozvytku [Ukrainian labor market: trends and features of development]. Visnyk Khmelnytskoho natsionalnoho universytetu. Ekonomichni nauky, vol. 5(1), pp. 165-170. (in Ukrainian)

9. Sorokin P. (1992) Chelovek. Tsivilizatsiya. Obschestvo [Human. Civilization. Society]. (in Russian)

10. Shaulska L. V. (2015). Novi rysy sfery zainiatosti ta perspektyvy yii rehuliuvannia [New features of employment sphere and prospects for its regulation]. Teoretychni i praktychni aspekty ekonomiky ta intelektualnoi vlasnosti, vol. 2(1), pp. 120-128. (in Ukrainian) 